\title{
MODEL PEMBELAJARAN TUGAS TERSTRUKTUR UNTUK MENINGKATKAN MOTIVASI DAN PRESTASI BELAJAR DALAM MENGENAL MAKNA PENINGGALAN SEJARAH
}

\author{
Wulyaningsih \\ Kepala SDN Bendung I Kec. Jetis Kab. Mojokerto \\ Email: wulyaningsih@gmail.com
}

\begin{tabular}{l}
\hline Tersedia Online di \\
\hline http://www.jurnal.unublitar.ac.id/ \\
index.php/briliant \\
\hline Sejarah Artikel \\
\hline Diterima pada 5 Januari 2017 \\
Disetuji pada 22 Januari 2017 \\
Dipublikasikan pada 1 Februari \\
2017 Hal. 51 - 57 \\
\hline Kata Kunci: \\
\hline tugas terstruktur, motivasi dan \\
prestasi belajar, peninggalan \\
sejarah
\end{tabular}

\begin{abstract}
Abstrak: Tujuan penelitian tindakan ini adalah: (a) Untuk mengungkap pengaruh pembelajaran terstruktur dengan pemberian tugas terhadap hasil belajar Pengetahuan Sosial. (b) Untuk mengungkap pembelajaran terstruktur dengan pemberian tugas terhadap motivasi belajar Pengetahuan Sosial. Penelitian ini menggunakan penelitian tindakan (action research) sebanyak tiga putaran. subyek penelitian ini adalah siswa Kelas V SDN Bendung-1 Kec. Jetis Kabupaten Mojokerto. Dari hasil analis didapatkan bahwa prestasi belajar siswa mengalami peningkatan dari siklus I sampai siklus III yaitu, siklus I (65\%), siklus II (71\%), siklus III (81\%). Berdsarkan penelitian ini adalah menunjukkan bahwa model pembelajaran terstruktrur dengan pemberian tugas dapat berpengaruh positif terhadap motivasi belajar Siswa SDN Bendung1 Kecamatan Jetis Kabupaten Mojokerto.
\end{abstract}

Dalam upaya peningkatan kualitas sekolah, tenaga kependidikan yang meliputi, tenaga pendidik, pengelola satuan pendidikan, penilik, pengawas, peneliti, teknis sumber belajar, sangat diharapkan berperan sebagaimana mestinya dan sebagai tenaga kependidikan yang berkualitas. Tenaga pendidik/guru yang berkualitas adalah tenaga pendidik/guru yang sanggup, dan terampil dalam melaksanakan tugasnya. Tugas utama guru adalah bertanggung jawab membantu anak didik dalam hal belajar. Dalam proses belajar mengajar, gurulah yang menyampaikan pelajaran, memecahkan masalah-masalah yang terjadi dalam kelas, membuat evaluasi belajar siswa, baik sebelum, sedang maupun sesudah pelajaran berlangsung (Combs, 1984:11-13). Untuk memainkan peranan dan melaksanakan tugas-tugas itu, seorang guru diharapkan memiliki kemampuan professional yang tinggi. Dalam hubungan ini maka untuk mengenal siswasiswanya dengan baik, guru perlu memiliki kemampuan untuk melakukan diagnosis serta mengenal dengan baik cara-cara yang paling efektif untuk membantu siswa tumbuh sesuai dengan potensinya masing-masing.

Proses pembelajaran yang dilakukan guru memang dibedakan keluasan cakupannya, tetapi dalam konteks kegiatan belajar mengajar mempunyai tugas yang sama. Maka tugas mengajar bukan hanya sekedar menuangkan bahan pelajaran, tetapi teaching is primarily and always the stimulation of learner (Wetherington, 1986:131-136), dan mengajar tidak hanya dapat dinilai dengan hasil penguasaan mata pelajaran, tetapi yang terpenting adalah perkembangan

51 BRILLIANT: Jurnal Riset dan Konseptual Volume 2 Nomor 1, Februari 2017 
pribadi anak, sekalipun mempelajari pelajaran yang baik, akan memberikan pengalaman membangkitkan bermacam-macam sifat, sikap dan kesanggupan yang konstruktif.

Sementara itu teknologi pembelajaran adalah salah satu dari aspek tersebut yang cenderung diabaikan oleh beberapa pelaku pendidikan, terutama bagi mereka yang menganggap bahwa sumber daya manusia pendidikan, sarana dan prasarana pendidikanlah yang terpenting. Padahal kalau dikaji lebih lanjut, setiap pembelajaran pada semua tingkat pendidikan baik formal maupun non formal apalagi tingkat Sekolah Dasar, haruslah berpusat pada kebutuhan perkembangan anak sebagai calon individu yang unik, sebagai makhluk sosial, dan sebagai calon manusia seutuhnya. Khususnya dalam pembelajaran Pengetahuan Sosial, agar siswa dapat memahami materi yang disampaikan guru dengan baik, maka proses pembelajaran terstruktur, guru akan memulai membuka pelajaran dengan menyampaikan kata kunci, tujuan yang ingin dicapai, baru memaparkan isi dan diakhiri dengan memberikan soal-soal kepada siswa.

Berdasarkan uraian di atas ditemukan beberapa permasalahan dalam pembelajaran Ilmu Pengetahuan Sosial (IPS) di kelas V SDN Bendung-1 Kecamatan Jetis , Kabupaten Mojokerto, yaitu rendahnya nilai hasil ulangan Ilmu Pengetahuan Sosial (IPS) kelas V SDN Bendung-1. Hal ini dapat diketahui dari hasil tes awal siswa kelas V SDN Bendung-1 Kecamatan Jetis, Kabupaten Mojokerto. Observasi awal menunjukkan bahwa siswa kelas V SDN Bendung-1 dinyatakan belum mencapai target yang telah ditentukan. Dari 30 siswa dapat mencapai kriteria ketuntasan minimum (KKM) sebanyak 7 siswa dengan persentase keberhasilan $23 \%$, sedangkan siswa yang belum mencapai KKM sebanyak 23 siswa dengan persentase keberhasilan $77 \%$. Nilai rata-rata tes awal mata pelajaran IPS siswa kelas V SDN Bendung 1 adalah 59,17 dengan persentase keberhasilan $59 \%$. Maka dari itu pembelajaran IPS di SDN Bendung-1 dinyatakan "belum tuntas", sehingga perlu diadakan penelitian untuk melihat pengaruh dari tugas terstruktur terhadap prestasi belajar siswa.

Pembelajaran tersetruktur, adalah bentuk pembelajaran sistematis yang berorientasi pada tujuan yang ingin dicapai. Pembelajaran ini meliputi tugas terstruktur, dimana tugas ini merupakan kegiatan kurikuler sebagai sarana untuk mencapai tujuan pembelajaran. Tugas terstruktur dapat diberikan kepada siswa di luar proses pembelajaran. Tujuan pemberian tugas terstruktur adalah untuk menunjang pelaksanaan program intrakurikuler. Tujuan tersebut juga agar siswa dapat lebih menghayati bahan-bahan pelajaran yang telah dipelajarinya serta melatih siswa untuk melaksanakan tugas secara bertanggung jawab.

Bentuk Pelaksanaan Tugas Terstruktur dapat dilaksanakan secara perorangan maupun kelompok. Kerja kelompok mempunyai arti yang sangat penting untuk mengembangkan sikap bergotong-royong, tenggang rasa, persaingan sehat, kerjasama dalam kelompok dan kemampuan memimpin. Jenis tugas hendaknya juga disesuaikan dengan jumlah anggota kelompok, sehingga tugas benar-benar dapat dilakukan secara kelompok. Jadi tugas yang tidak seharusnya diberikan secara kelompok dapat menimbulkan kesulitan-kesulitan baru bagi siswa, sedangkan tugas perorangan mempunyai makna untuk mengembangkan sikap mandiri dan memungkinkan penyesuaian kegiatan belajar 
dan minat serta kemampuan siswa. Dengan memperhatikan pelaksanaan Pembelajaran terstruktur maka diharapkan aktivitas belajar siswa dan prestasi belajar akan meningkat.

\section{METODE}

Jenis Penelitian adalah Penelitian Tindakan Kelas (PTK). Penelitian tindakan kelas adalah suatu penelitian yang reflektif. Kegiatan penelitian berasal dari permasalahan yang riil yang dihadapi oleh guru dalam proses belajar mengajar, kemudian direfleksikan alternative pemecahan masalahnya dan ditindaklanjuti dengan tindakan-tindakan nyata yang terencana dan terukur.

Hal penting dalam PTK adalah tindakan nyata yang dilakukan guru (dan bersama pihak lain) untuk memecahkan masalah yang dihadapi dalam proses belajar mengajar. Tindakan itu harus direncanakan dengan baik dan dapat diukur tingkat keberhasilannya dalam pemecahan masalah tersebut. Jika ternyata program itu belum dapat memecahkan masalah yang ada, maka perlu dilakukan penelitian siklus berikutnya.

\section{Subyek Penelitian}

Subyek penelitian ini adalah kelas V SDN Bendung I Kecamatan Jetis, Kabupaten Mojokerto. Dengan jumlah siswa sebanyak 30 orang siswa yang terdiri atas 16 orang siswa laki-laki dan 14 orang siswa perempuan. Karakteristik siswa kelas V SDN Bendung I Kecamatan Jetis sangat heterogen yaitu Siswa yang tingkat kemampuan barfikirnya tinggi sebanyak 8 orang, tingkat kemampuan berfikirnya sedang sebanyak 10 orang, sedangkan tingkat kemampuan berfikirnya rendah sebanyak 12 orang.

\section{Lokasi Penelitian}

Lokasi penelitian adalah tempat yang digunakan dalam melakukan penelitian untuk memperoleh data yang diinginkan. Penelitian ini bertempat di SDN Bendung I Kecamatan Jetis, Kabupaten Mojokerto. Lokasi SDN Bendung I berada di desa Bendung, Kecamatan Jetis Kabupaten Mojokerto.

\section{Waktu Penelitian}

Waktu penelitian adalah waktu berlangsungnya penelitian atau saat penelitian ini dilangsungkan. Penelitian ini dilaksanakan pada bulan Februari Mei 2016 Tahun ajaran 2011-2016. Waktu penelitian ini dilaksanakan tanggal 8 Maret, 15 Maret, dan 5 April 2016.

\section{Deskripsi Persiklus}

Dalam penelitian ini dilaksanakan dalam tiga siklus. Hal ini dilaksanakan agar peneliti dapat memperbaiki tindakan dalam setiap siklus untuk menemukan cara paling efektif dan efisien dari penerapan metode ini.

\section{Siklus Pertama}


Tahap Rencanaan Perbaikan. Siklus pertama dilaksanakan pada hari Selasa,, tanggal 8 Maret 2016 dengan alokasi waktu 2x35 menit. Pelaksanaan perbaikan. Adapun langkah-langkah yang ditempuh dalam proses perbaikan pembelajaran IPS dengan menggunakan pembelajaran terstruktur mengacu pada RPP siklus I yang telah dibuat.

Pengamatan. Pada tahap ini adalah mengamati hasil atau dampak dari diterapkannya model pembelajaran terstruktur. Pada saat melaksanakan pengamatan peneliti dibantu oleh teman sejawat dan dilaksanakan bersamaan dengan pelaksanaan belajar mengajar.

Refleksi. Pada tahap refleksi ini kegiatan meliputi analisis data yang diperoleh melalui observasi pengamatan. Berdasarkan hasil observasi tersebut, guru dapat merefleksikan diri tentang kegiatan pembelajaran yang telah dilakukan. Dengan demikian, guru akan dapat mengetahui efektivitas kegiatan pembelajaran yang telah dilakukan. Berdasarkan hasil refleksi ini akan dapat diketahui kelemahan kegiatan pembelajaran yang dilakukan oleh guru sehingga dapat digunakan untuk menentukan tindakan pada siklus selanjutnya.

\section{Instrumen Penelitian}

Instrumen yang digunakan dalam penelitian ini terdiri dari: (1) Silabus, yaitu seperangkat rencana dan pengaturan tentang kegiatan pembelajaran pengelolahan kelas, serta penilaian hasil belajar. (2) Rencana Pelaksanaan Pembelajaran (RPP), yaitu merupakan perangkat pembelajaran yang digunakan sebagai pedoman guru dalam mengajar dan disusun untuk tiap putaran. (3) Lembar Kegiatan Siswa. Lembar kegiatan ini yang dipergunakan siswa untuk membantu proses pengumpulan data hasil kegiatan pemberian tugas. (4) Lembar Observasi Kegiatan Belajar Mengajar. Lembar observasi pengolahan pembelajaran terstruktur dengan pemberian tugas, untuk mengamati kemampuan guru dalam mengelola pembelajaran. (5) Tes formatif. Tes ini disusun berdasarkan tujuan pembelajaran yang akan dicapai, digunakan untuk mengukur kemampuan pemahaman konsep Pengetahuan Sosial pada pokok bahasan kerajaan Hindu, Budha dan Islam di Indonesia. Tes formatif ini diberikan setiap akhir putaran. Bentuk soal yang diberikan adalah isian (esai) sejumlah 10 butir soal.

\section{Analisis Data}

Untuk menganalisis tingkat keberhasilan atau persentase keberhasilan siswa setelah proses belajar mengajar setiap putarannya dilakukan dengan cara memberikan evaluasi berupa soal tes tertulis pada setiap akhir putaran. Analisis ini dihitung dengan menggunakan statistik sederhana yaitu (1) Untuk menilai ratarata ulangan atau tes formatif menggnakan rumus rata-rata. (2) Untuk ketuntasan belajar. Ada dua kategori ketuntasan belajar yaitu secara perorangan dan secara klasikal. Seorang siswa dikatakan tuntas belajar bila telah mencapai skor $65 \%$ atau nilai 65 , dan kelas disebut tuntas belajar bila di kelas tersebut terdapat $85 \%$ yang telah mencapai daya serap lebih.

\section{HASIL DAN PEMBAHASAN}

54 BRILLIANT: Jurnal Riset dan Konseptual Volume 2 Nomor 1, Februari 2017 


\section{Kemampuan Guru dalam Mengelola Pembelajaran}

Berdasarkan analisis data, diperoleh aktivitas siswa dalam proses pembelajaran terstrutur dengan pemberian tugas dalam setiap siklus mengalami peningkatan. Hal ini berdampak positif terhadap proses mengingat kembali materi pelajaran yang telah diterima selama ini, yaitu dapat ditunjukkan dengan meningkatnya nilai rata-rata aktifitas belajar siswa pada setiap siklus yang terus mengalami peningkatan. Dapat dilihat dari grafik perubahan.

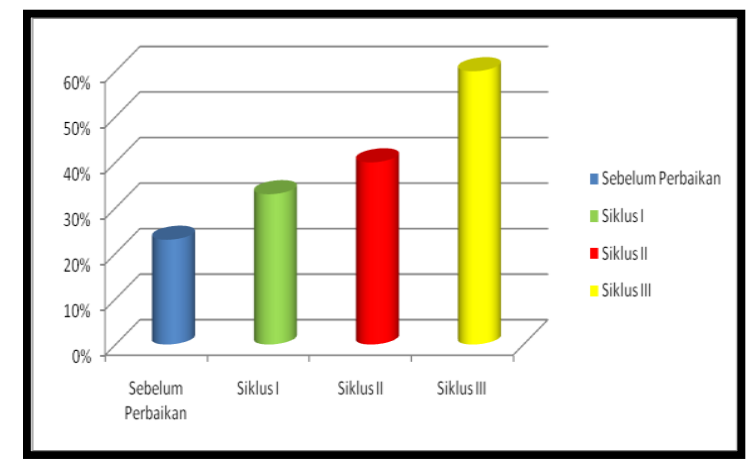

\section{Grafik 1.Perubahan Tingkat Keaktifan Siswa}

Rata-rata tingkat keaktifan siswa naik, sebelum pembelajaran $23 \%$, siklus I $33 \%$, siklus II $40 \%$, siklus III $60 \%$. Rata-rata hasil belajar (nilai tes formatif) siswa naik sebelum pembelajaran 59\%, siklus I 65\%, Siklus II $71 \%$, dan siklus III $81 \%$.

Sedangkan untuk aktivitas guru selama pembelajaran telah melaksanakan langkah-langkah belajar aktif dengan baik. Hal ini terlihat dari aktivitas guru yang muncul di antaranya aktivitas membimbing dan mengamati siswa dalam mengerjakan kegiatan, menjelaskan, memberi umpan balik/evaluasi/tanya jawab dimana prosentase untuk aktivitas di atas cukup besar. Berdasarkan hasil pengamatan di atas menunjukkan bahwa aktifitas guru pada siklus I telah mencapai 55,56 \% dari yang diharapkan. Masih ada empat butir pernyataan yang belum dilaksanakan oleh guru yaitu : 1) guru belum maksimal dalam memberikan motivasi terhadap siswa, 2) guru tidak menyampaikan tujuan pembelajaran yang akan dilaksanakan dalam pembelajaran, 3) langkah - langkah yang akan ditempuh dalam pembelajaran tidak didiskusikan terlebih dahulu, 4) guru belum maksimal membimbing siswa membuat rangkuman.

Hasil pengamatan siklus II menunjukkan bahwa aktifitas guru telah mencapai 66,67 \% dari yang diharapkan. Masih ada tiga butir pernyataan yang belum dilaksanakan oleh guru yaitu : 1) guru belum menyampaikan pembelajaran yang akan dilaksanakan, 2) guru tidak mendiskusikan langkah - langkah apa yang akan ditempuh dalam proses perbaikan, 3) guru belum maksimal membimbing siswa membuat rangkuman materi yang telah dipelajari. tiga hal di atas akan dijadikan bahan kajian refleksi pada siklus III.

Hasil pengamatan pada siklus III menunjukkan bahwa aktifitas guru telah mencapai $100 \%$ sesuai dengan yang diharapkan.

\section{Ketuntasan Hasil belajar Siswa}

55 BRILLIANT: Jurnal Riset dan Konseptual

Volume 2 Nomor 1, Februari 2017 
Melalui hasil penelitian ini menunjukkan bahwa pembelajaran terstrutur dengan pemberian tugas memiliki dampak positif dalam meningkatkan prestasi belajar siswa. Hal ini dapat dilihat dari semakin mantapnya pemahaman dan penguasaan siswa terhadap materi yang telah disampaikan guru selama ini (ketuntasan belajar meningkat dari sklus I, II, dan III) yaitu masing-masing 65\%, $71 \%$, dan $81 \%$. Pada siklus III ketuntasan belajar siswa secara klasikal telah tercapai. Ketuntasan hasil belajar siswa dalam bentuk grafik peneliti sajikan pada grafik. 2

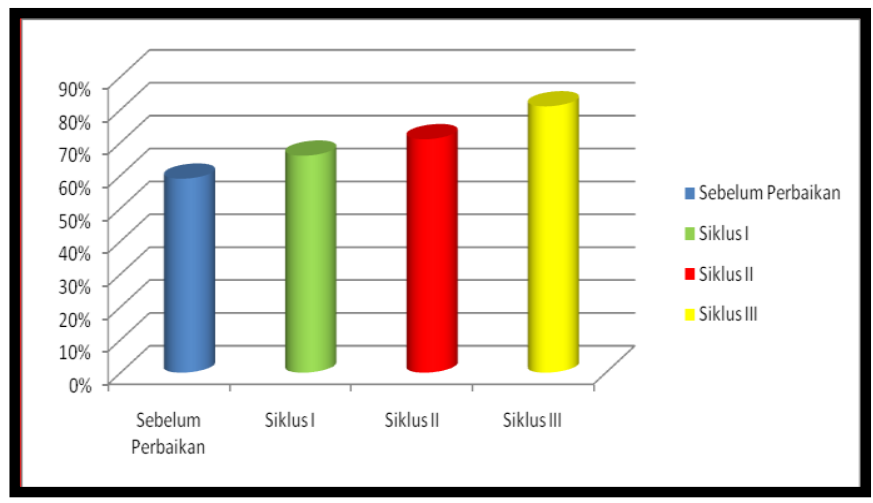

Grafik. 2 Ketuntasan Hasil Belajar Siswa siklus I,II dan III

\section{KESIMPULAN}

Berdasarkan hasil penelitian yang telah dikemukakan pada bab IV sebelumnya, maka kesimpulan yang dapat ditarik dalam penelitian ini adalah sebagai berikut: (1) Pembelajaran terstruktur dengan pemberian tugas memiliki dampak positif dalam meningkatkan prestasi belajar siswa yang ditandai dengan peningkatan ketuntasan belajar siswa dalam setiap siklus, yaitu siklus I (57\%), siklus II (70\%), siklus III (87\%). (2) Penerapan pembelajaran terstruktur dengan pemberian tugas mempunyai pengaruh positif, yaitu dapat meningkatkan motivasi belajar siswa yang ditunjukan dengan rata-rata jawaban siswa yang menyatakan bahwa siswa tertarik dan berminat terhadap pembelajaran terstruktur dengan pemberian tugas sehingga mereka menjadi termotivasi untuk belajar.

\section{SARAN}

Dari hasil penelitian yang diperoleh dari uraian sebelumnya agar proses belajar mengajar Pengetahuan Sosial lebih efektif dan lebih memberikan hasil yang optimal bagi siswa, maka disampaikan saran sebagai berikut: (1) Untuk melaksanakan pembelajaran terstruktur dengan pemberian tugas memerlukan persiapan yang cukup matang, sehingga guru harus mampu menentukan atau memilih topik yang benar-benar bisa diterapkan dengan pembelajaran terstruktur dengan pemberian balikan dalam proses belajar mengajar sehingga diperoleh hasil yang optimal. (2) Dalam rangka meningkatkan prestasi belajar siswa, guru hendaknya lebih sering melatih siswa dengan berbagai metode, walau dalam taraf yang sederhana, dimana siswa nantinya dapat menemukan pengetahuan baru, 
memperoleh konsep dan keterampilan, sehingga siswa berhasil atau mampu memecahkan masalah-masalah yang dihadapinya. (3) Perlu adanya penelitian yang lebih lanjut, karena hasil penelitian ini hanya dilakukan di SDN Mojotamping Kec. Bangsal , Kab. Mojokerto. (4) Untuk penelitian yang serupa hendaknya dilakukan perbaikan-perbaikan agar diperoleh hasil yang lebih baik.

\section{DAFTAR PUSTAKA}

Arikunto, Suharsimi. 2002. Prosedur Penelitian Suatu Pendekatan Praktek. Jakarta: Rineksa Cipta.

Combs. Arthur. W. 1984. The Profesional Education of Teachers. Allin and Bacon, Inc. Boston.

Departemen Pendidikan dan Kebudayaan, 1994. Petunjuk Pelaksanaan Proses Belajar Mengajar, Jakarta. Balai Pustaka.

Ngalim, Purwanto M. 1990. Psikologi Pendidikan. Bandung: PT. Remaja Rosdakarya. 